\title{
The impact of climate change awareness on behavioral changes in Germany: changing minds or changing behavior?
}

Sandra Venghaus ${ }^{1,2^{*}} \mathbb{0}$, Meike Henseleit ${ }^{1}$ and Maria Belka ${ }^{1}$

\begin{abstract}
Background: The increasing frequency of extreme weather events across the globe, the intensifying international debates about the political urgency to mitigate climate change, as well as the respective more action demanding social movements have caused a significant increase in climate change awareness among the population. Little research, however, has systematically analyzed the behavioral impact of this development. Using Germany as a case study, we therefore scrutinize whether the recent increase in climate change awareness triggered mainly changes in public perceptions concerning environmental and sustainability issues or whether it has led to sustainable behavioral shifts. Based on previous research, we considered two routes through which an increase in climate change awareness can instigate changes: (a) directly by leading to behavioral changes towards more sustainable consumption decisions, or (b) indirectly by exerting pressure on the political process.

Results: The analyzed data in the three consumption sectors of mobility, food consumption and housing confirm the continuing prevalence of an attitude-behavior gap: although there is a broad, strongly positive attitude towards climate protection and increasingly high problem awareness of climate change, so far this attitude does not immediately translate into notable behavioral changes. With regard to effects on political agenda setting, however, the effects are much more immediate. The results confirm strong pressure on the political process mainly through shifts in voter behavior.

Conclusions: The results show that the increase in climate change awareness has spurred dynamics in the debate around climate change both among the population and in the political realm. Fueled by the intense media coverage of the Fridays For Future movement and related activities, a snowball effect has been set off, opening a window of opportunity for significant shifts towards more effective and rigorous climate policies. Politicians and decision-makers now have the opportunity to implement sustainability measures with strong support of the population, even if these imply higher costs. Whether there will be further shifts in the current lifestyle towards a more sustainable one, lifestyle changes should be carefully monitored in the coming years, as relevant data are only now becoming available.
\end{abstract}

Keywords: Climate change, Climate change awareness, Germany, Behavioral change

*Correspondence: venghaus@socecon.rwth-aachen.de

2 School of Business and Economics, RWTH Aachen, 52072 Aachen, Germany

Full list of author information is available at the end of the article

\section{Background}

The past three years have been characterized by noticeable changes that propose a significant increase in general climate change awareness among the population. This trend reflects itself not least in the immense number of protest events that have taken place over the past years-often under the umbrella of the Fridays For original author(s) and the source, provide a link to the Creative Commons licence, and indicate if changes were made. The images or other third party material in this article are included in the article's Creative Commons licence, unless indicated otherwise in a credit line to the material. If material is not included in the article's Creative Commons licence and your intended use is not permitted by statutory regulation or exceeds the permitted use, you will need to obtain permission directly from the copyright holder. To view a copy of this licence, visit http://creativecommons.org/licenses/by/4.0/. The Creative Commons Public Domain Dedication waiver (http://creativeco mmons.org/publicdomain/zero/1.0/) applies to the data made available in this article, unless otherwise stated in a credit line to the data. 
Future movement-demanding more action for climate change. This movement emerged following Greta Thunberg's strike for climate action in front of the Swedish parliament in August 2018, after which more and more students joined in order to support her claim for more climate action in Sweden. Coincidentally, at the time when an unusual hot period and drought covered Europe [1], within only 3 months, the strike for more active climate action had spread rapidly across the world to Australia, Belgium, France, Finland and Denmark [2]. By the end of the year, almost 10,000 students demonstrated in Australia and more than 1,000 students in Belgium [3]. The Hashtag \#FridaysForFuture emerged [4]. Between August 2018 and October 2019, the movement organized over 49,000 events in over 6,300 cities across 215 countries [5]. In total, during the same period 8.6 million people participated in the strikes [5]. The Fridays For Future movement was thus extremely successful with respect to its geographic scope and the globally mobilized strike participation.

In 2019, the Youth Study conducted by Shell further supports the assumption of growing climate change awareness: whereas in 2015 younger generations were most afraid of terror attacks, in 2019 climate change and environmental pollution were perceived as the highest threat by $66 \%$ of all interviewees [6]. A further finding of the study was that $71 \%$ of all interviewees identified protection of the environment to be much more important than a high living standard [6].

However, where these developments provide an obvious indication that the increasing climate change awareness has mobilized a large number of people to strike and protest for more action on climate change, little research has explicitly addressed the behavioral impacts. In this paper, we therefore have focused on examining behavioral changes in consumption decisions related to increased climate change awareness using Germany as a case study. To analyze behavioral changes, we review the available data to identify how far climate change awareness has in fact manifested itself in behavioral changes towards climate protection, or whether it halts in the minds of people merely leading to controversial debates and either no or ambivalent behavioral responses in Germany. Based on previous research [e.g., 7, 8], we can hypothesize that a significant change in climate change awareness not only affects the public perception, but also translates into noticeable changes in people's behavior. These effects may take two routes-positively in the form of behavioral confirmation (i.e., information leads to positive reinforcement), or adversely in the form of protest behavior $[9,10]$.

Accordingly, the remainder of this paper is structured as follows. In Sect. 2, we further elaborate the research background by describing recent developments regarding climate change awareness and the contribution of household consumption decisions to $\mathrm{CO}_{2}$ emissions in Germany. In Sect. 3, the analytical research approach is introduced. The results of the study are presented in Sect. 4, differentiated between findings relating to consumption decisions (4.1), and effects relating to voter behavior (4.2) in Germany, and all results are discussed in Sect. 5. Conclusions drawn from these results are further discussed in the final Sect. 6 .

\section{Climate change awareness and sustainable consumption}

During the last decade, various surveys have confirmed a strong increase in public concern about climate change among the population [11-19]. One in three people (37\%), for example, state they believe that global warming/climate change is the number one environmental concern (Germany: 50\%) [19], and about $80 \%$ of people are of the opinion that urgent action is needed to combat the climate crisis (in Germany: 73\%), as a survey conducted in 2019 in 27 countries showed [18]. Currently, the social sustainability barometer of the German energy transition confirms that over $90 \%$ of the German population generally approves and politically supports the common project of the "Energiewende" [20]. However, at the same time, only $28 \%$ of the population states a positive willingness to pay more, e.g., for car or air travel in order to protect the climate [20]. The numbers well support the previous research, which has demonstrated that especially the topics of sustainability and climate change are prone to the so-called attitude-behavior gap: especially environmental attitudes of people only loosely translate into actions able to effectively reduce their environmental impact [21-23]. So while there is generally a very strong supportive attitude towards climate protection and sustainability as a concept (including a stated willingness to act), this individual willingness to act is often inferior to other factors, e.g., cost considerations, convenience or perceived responsibility [24]. According to the low-cost hypothesis of environmental behavior, environmental attitudes typically only promote "green" actions when the related behavioral costs, i.e., the 'burden' of behavioral change, are low, as, for example, in the case of turning off lights when leaving a room, buying organic food, or separating waste [21]. Concerned people use low-cost actions to reduce the cognitive dissonance between their concern for the environment and rational realization of the environmental impact of their actions, while avoiding costly actions despite their higher effectiveness [25]. Changes in behavior which imply higher personal behavioral costs like not taking the car to work or reducing air travel are translated into action much more rarely.

With respect to the climate effects of households, only roughly one-third (33.6\%) of $\mathrm{CO}_{2}$ emissions are caused 
Table 1 Indicators listed by the sector considered in the analysis

\begin{tabular}{|c|c|c|}
\hline Sector & Indicator & Source \\
\hline \multirow[t]{4}{*}{ Mobility } & Share of SUVs in new vehicle registrations (-) & [29] \\
\hline & Total number of air passengers $(-)$ & [30] \\
\hline & Total railway mileage $(+)$ & {$[30]$} \\
\hline & Budget spent on carbon offset (+) & $\begin{array}{l}\text { Data provided by suppliers } \\
\text { (e.g., Atmosfair; PrimaKlima, } \\
\text { MyClimate) }\end{array}$ \\
\hline \multirow[t]{3}{*}{ Food consumption } & Meat consumption (-) & [31] \\
\hline & Consumption of organic food $(+)$ & [32] \\
\hline & Share of vegetarians in the population $(+)$ & [33] \\
\hline Housing & $\begin{array}{l}\text { Consumption of electricity from renewable sources (green electricity) } \\
(+)\end{array}$ & [34] \\
\hline
\end{tabular}

(+) positive impact on climate change mitigation

(-) negative impact on climate change mitigation

by direct emissions, whereas indirect emissions embedded in consumer goods account for the dominant share of $66.4 \%$. These indirect effects are split almost equally across energy products (19.0\%), goods (24.4\%), and services (23.1\%) [26]. Thus, household decisions, especially in high-income countries such as those in North America, Europe or Australia, play a key role in reaching the goals of the Paris Agreement [27]. In order to select the most relevant categories, we therefore surveyed those consumption categories for data, which most significantly contribute to the carbon footprint of households in high-income countries. Specifically, these are (a) mobility (accounting for roughly 30\% of household GHG emissions in Germany); (b) food consumption (accounting for roughly 30\% of household GHG emissions in Germany), and (c) housing (accounting for roughly $20 \%$ of household GHG emissions in Germany) [27, 28]. In sum, these three sectors account for over $80 \%$ of total German household GHG emissions.

Given this relevance of household consumption decisions for the mitigation of climate change, in the following we address the question as to whether the identified increase in the level of climate change awareness actually bridges the attitude-behavior gap. The following review of available empirical data shall shed light on this question. In order to determine, whether there is actually a measurable effect in terms of behavioral change in Germany, we surveyed the available data within the three categories mentioned above.

\section{Research approach and method}

A first step thus consisted in reviewing the available information on recent developments in mobility behavior, food consumption and housing choices for the case study Germany. For the three sectors under consideration, a search was conducted for key indicators, before the identified information was qualitatively analyzed in order to describe their relevance in the context of climate change awareness. The data search included both available scientific publications and reports, as well as raw data from the German national and federal statistical offices, government data, as well as data from personal correspondence with scientists and companies. For the latter to be considered in the study, the data needed to fulfill the following two criteria: (a) relevance to the objectives of the Fridays For Future movement (i.e., primarily climate protection), and (b) availability of a time series to cover the relevant period of change (i.e., between 2016 and 2019). Following the search, the available data were screened for relevance, adequacy and completeness. The search resulted in the following data to be considered (Table 1).

In a next step, the data were then reviewed and analyzed with respect to noticeable changes and change rates over the relevant period from 2016 to 2019 . Although at this point data would also be available for the year 2020, consumption behavior during this year was heavily influenced by the global Covid-19 pandemic. Accordingly, this year is not considered in the analysis.

\section{Analysis and results \\ Consumption decisions}

In order to identify and trace the changes in behavior over the relevant period from 2016 until 2019 and to compare the differences among the selected indicators for the considered sectors of mobility, food consumption and housing, the respective growth rates over the years were calculated (Table 2). For an overview of the absolute data, see Table 3 in the appendix. As the data overview shows, there is currently no clear evidence that increasing climate change awareness has actually led to significant behavioral changes. There are two indicators, which 
Table 2 Development of indicators from 2016 until 2019

\begin{tabular}{|c|c|c|c|c|c|}
\hline Sector & Indicator & $\begin{array}{l}\text { Growth } \\
\text { Rate I }\end{array}$ & $\begin{array}{l}\text { Growth } \\
\text { Rate II }\end{array}$ & $\begin{array}{l}\text { Growth } \\
\text { Rate III }\end{array}$ & $\begin{array}{l}\text { Development } \\
\text { Growth Rate }\end{array}$ \\
\hline & & $(2016 / 2017)$ & 2017/2018) & (2018/2019) & III \\
\hline \multirow[t]{3}{*}{ Mobility } & $\%$ of SUVs of the registration of new cars & $19.7 \%$ & $20.4 \%$ & $15.8 \%$ & \\
\hline & number of air passengers in 1000 & $3.4 \%$ & $5.1 \%$ & $4.2 \%$ & \\
\hline & Railway mileage in mill. Km & $1.4 \%$ & $2.7 \%$ & $2.0 \%$ & \\
\hline \multirow[t]{3}{*}{ Food consumption } & Meat in kg/capita/year & $-0.8 \%$ & $0.3 \%$ & $-1.2 \%$ & \\
\hline & Expenses for organic food in billion $€$ & $5.1 \%$ & $5.5 \%$ & $9.7 \%$ & \\
\hline & Vegetarians in million people & $7.8 \%$ & $10.7 \%$ & $-3.3 \%$ & \\
\hline Housing & Million people consuming green electricity & $7.9 \%$ & $8.7 \%$ & $10.9 \%$ & \\
\hline
\end{tabular}

Sources: see Table 1

may signal a trend towards more sustainable consumption decisions. For the development of the share of SUVs in new vehicle registrations the growth rate decreased from $19.7 \%$ and $20.4 \%$, respectively, for the previous two periods (i.e., $2016 / 2017$ and $2017 / 2018$ ) to $15.8 \%$ for the period from 2018 to 2019. It is, however, not distinguishable from the data, whether this trend is in fact induced by increased environmental awareness or by an incipient market saturation. Over the same periods, the growth rate for the number of people consuming electricity from renewable sources increased from $7.9 \%$ and $8.7 \%$ between $2016 / 2017$ and $2017 / 2018$, to $10.9 \%$ between 2018 and 2019. However, counter to these developments, the number of vegetarians decreased by $3.3 \%$ for the period $2018 / 2019$, whereas it had increased by $7.8 \%$ and $10.7 \%$, respectively, during the periods of $2016 / 2017$ and 2017/2018.

Because these selective data only indicatively address an extract of behavioral changes in the sectors, in the following the developments in the sectors will be described in further detail.

\section{Mobility}

As indicated in Table 2, for the purpose of analyzing consumption behavior in the sector of mobility, specific consideration was given to three modes of transportation-namely passenger vehicle use, airplane travel, and railway travel. Globally it is estimated that transportation is responsible for about $22 \%$ of the total greenhouse gas emissions, with road transportation accounting for roughly three quarters of this share. Whereas passenger vehicles and trucks contribute roughly equal shares (i.e., about 35\% each), aviation and maritime transportation account for $11 \%$ each [35]. Furthermore, although aviation only accounts for $2 \%$ of the total anthropogenic $\mathrm{CO}_{2}$ emissions, its contribution to climate change is estimated to be in the order of $5 \%$, given that the emissions occur at flying altitude with additional, albeit transient, atmospheric warming effects [36].

In Germany, individual passenger vehicle use accounts for $76 \%$ of the total mileage, of which about $43 \%$ is attributed to recreational purposes like vacationing, hobbies, meeting friends, etc. The remaining mileage is split between commuting (22\%), business trips (15\%), and detours for dropping of or picking up people (5\%) [37]. This distribution has remained roughly stable over the last decades [38].

Although there has long been a profound understanding of the detrimental climate effects of motorized transport, many studies confirm a lasting attitude-behavior gap between acknowledging these negative climate effects of automotive use and the consequentially needed reduction to mitigate its climate effects [39-41]. Consistent with these findings, the increasing climate change awareness and the Fridays For Future movement so far have not had a significant reductive effect, neither on the number of passenger vehicle registrations [42], nor on the mileage per vehicle [43]. The same holds true for 
the passenger vehicle mileage per person with nearly identical values for 2017 and $2018^{1}$ [44] and a slight increase for 2019 [45]. Instead, there has been a steady trend towards purchasing ever larger and uneconomical vehicles (Table 2). New vehicle registrations increased for both SUVs and off-road vehicles by $15.3 \%$ and $14.1 \%$. respectively, over the period from January until September 2019 as compared to the same period in 2018, whereas it decreased for both compact cars and mediumclass cars by $3.2 \%$ and $5.1 \%$, respectively [42].

Furthermore, the year 2019 marked a new record high in the number of airplane passengers for Germany [4649]. Compared to the first six months of the year 2018, the number of passengers for non-domestic inter-European flights increased by $4.5 \%$ to a total of 47.3 million, with increases especially in flights to Turkey $(+370,000)$, Italy $(+266,000)$, and Spain $(+195,000)$. Similarly, but not as drastically, the number of passengers of domestic flights increased by $2.3 \%$ to a total of 11.6 million, whereas the passenger number of intercontinental flights increased by $3.5 \%$ to a total of 10.1 million [50]. However, for the second half of the year 2019, the Federal Association of the German Air Transport Industry (Bundesverband der Deutschen Luftverkehrswirtschaft) reported a notable decrease in domestic flights with $-2 \%$ for the third and $-9 \%$ for the fourth quarter in 2019 compared to the same period in 2018 [48, 49], amounting to a total reduction in domestic flights by about $1.8 \%$ [51]. Interestingly, in the home country of Greta Thunberg, Sweden, this picture looks different: according to the Scandinavian airline $\mathrm{SAS} A B$, at Swedish airports the number of passengers declined by $2 \%$ in 2019 compared to 2018, and Sweden's airport operator reported it handled 9\% fewer passengers for domestic flights in 2019 [52]. Reasons may include the following: on the one hand, the Swedish government introduced an air traffic tax in April 2018, which increases the price per ticket by between $5.80 €$ and 38.80 $€$ and, on the other hand, "flight-shaming", an anti-flying movement which emerged in 2017 after singer Staffan Lindberg had pledged to give up flying, boosted in 2019 following the campaigns by Greta Thunberg and other influential people, such as, e.g., filmmaker and naturalist David Attenborough or primatologist and anthropologist Jane Goodall $[47,53]$.

In several recent public and customer surveys [e.g., 14, 52, 54-56], a high willingness to overthink travel plans because of their climate impact was confirmed. A global survey of 19,023 adults conducted between June 21 and July 5, 2019, found that about one in seven consumers
(14\%) would use a form of transportation with a lower carbon footprint than air travel, even if it was less convenient or more expensive. Twice as many (29\%) would do so, if it was as convenient as or no more expensive than flying. Age (i.e., younger than 35 years) and education (i.e., higher education) had a positive impact on the willingness to choose a more environmentally benign form of transportation than flying [56]. However, the stated awareness of and willingness to consider the harmful effects of airplanes in their travel behavior so far has rarely affected behavior. In fact, the number of domestic flights decreased in the second half of the year 2019 in Germany. This, however, was likely driven by a slowing German economy and a reduction of overcapacity by airlines. Due to the Covid-19-pandemic in the first half of 2020, we will not be able to recognize at least until 2021, whether reductions in demand were actually driven by environmental motivation [49].

In addition to the increasing numbers of airplane passengers, also no significant rise in railway mileage has been reported for 2018 and 2019 [50] apart from a steady increase of around $2 \%$ per year. However, with the increasing awareness of the negative climate impacts of air travel, the willingness to pay for flight carbon offsets is spurting upward. This trend seems to hold across a very broad range of organizations: Myclimate, a Swiss nonprofit organization, whose clients include Deutsche Lufthansa AG, reported a fivefold jump in its credits over the period from summer 2018 to summer 2019. At Ryanair Holdings Plc (Europe's largest discount carrier), the number of passengers deciding for voluntary carbon offset payments has almost doubled over 18 months. Verra, the largest program for voluntary carbon offset credits globally, reported their monthly usage rate for offsets jumped by $23 \%$ during 2019 to a high of 3.8 million tons a month [53]. In a personal correspondence with an employee of PrimaKlima, a German carbon offset organization, an enormous increase in private donations over the period from summer 2018 to summer 2019 was stated. Although these numbers confirm a significantly growing public demand for carbon offsets that is temporally correlated to the emergence of the Fridays For Future movement and the related increase in climate change awareness, it is important to keep in mind that this increase is referenced to a very low starting point. At Ryanair, for example, overall still less than $3 \%$ of the customers choose to purchase carbon offset credits, of which, however, the largest demand is registered from Germany [53]. Atmosfair, a German non-profit organization for greenhouse

${ }^{1}$ At the time of writing this paper (April 2020), the numbers for 2018 had not been finally confirmed. 
gas compensation, had a financial volume generated by voluntary donations of about 7 million $€$ in 2017, about 10 million $€$ in 2018, and about 20 million $€$ in 2019 [57]. The 2018 financial volume of PrimaKlima, according to a personal correspondence, was in the range of a "lower six-digit sum". Nonetheless, a clear trend is noticeable.

\section{Food consumption}

For almost two decades, total meat consumption in Germany had been stable at about $60 \mathrm{~kg}$ per capita per year, with in-home consumption steadily decreasing, and out-of-home consumption steadily rising. Recent variations indicated a slight decrease in total per capita meat consumption by $500 \mathrm{~g}$ for 2017, whereas for 2018 a small increase of $200 \mathrm{~g}$ per capita was reported [58]. A stronger decrease was observed for 2019 (59.7 kg per capita, i.e., 700 g less than in 2018) [59]. The decrease occurred nearly exclusively in pork meat and only to a small proportion in cattle, whereas the consumption of poultry slightly increased. Reasons for this ongoing trend may be the following:

availability of more meat-free alternatives, an increasing proportion of Muslims in Germany who forego pork meat for religious reasons, avoidance of pork meat for health reasons and a respective increase in poultry consumption, hot summers and thus fewer barbecues, increased awareness of climate change and environmental and ethical issues [60].

Future statistical data will have to show, whether this development was caused by the extraordinarily hot summers, or whether there will, in fact, be a continuous reduction in meat consumption in Germany. If the latter is the case, other variables need to be considered in order to recognize to what extent this change can be credited to climate and environmental consciousness.

Regarding organic food, in 2019 consumer expenses increased by nearly $10 \%$ compared to 2018 , which is a remarkable increment beyond the general trend of about $5 \%$ growth per year in this food sector. However, various factors may be responsible for this: on the one hand, demand grows faster than supply, which means that prices increase, and, thus, expenses also increase without an effect on the amount of purchased products [61]. Furthermore, the supply of organic products as well as sales channels get broader, including increasingly discounters and marketing activities for organic products. According to the German Federal Association of Natural Food Products [62], an increased environmental consciousness can be observed for organic retail in Germany: total sales of organic retail increased by $8.7 \%$ in 2019 , with an even higher increase in the second half of the year, which is unusual. According to BNN, this is due to an increased awareness of environmental and climate issues, evoked by the Fridays For Future movement and the prevalence of the topics in the media. An indicator for this is the increased number of purchased vouchers in 2019 compared to 2018 with on average also higher amounts per voucher in 2018. For comparison, in 2018 the number of vouchers was smaller than in 2017 , whereas the total amount per voucher was higher in 2018 than in 2017. This indicates that more people now purchase their food in organic retail stores, spending also more money there [62].

\section{Housing}

According to Verivox, the largest independent comparison portal in Germany, the number of newly concluded contracts of electricity from renewable sources ('green electricity') had been decreasing for years. However, recently a sharp increase was observed: in June 2019, $58 \%$ of consumers signing new contracts chose green electricity, whereas in June 2018 only $33 \%$ had done so. According to an energy expert of the platform, this increase can be attributed to the current climate debate: "Consumers are choosing increasingly green electricity when they feel affected by external incidents, like the atomic catastrophe of Fukushima in 2011" [63]. A similar trend was instigated by the global warming debate so strongly pushed into the public focus by Greta Thunberg and the awareness of climate change that was further fortified in Germany by the extreme heat waves of 2018 and 2019. Similar to the widespread increase in flight carbon offsets, this trend of increasing demand for green electricity is also consistently reported across various electricity suppliers. It was confirmed, for example, by the electricity provider E.on, who reported an increase in demand for green electricity of about $30 \%$ over the last 12 months from May 2018 until May 2019, and who likewise attributes the reason for this increase to the current public discourse about global warming [64]. Also, the green electricity provider Lichtblick observed a remarkable increase in the demand for green electricity by over 


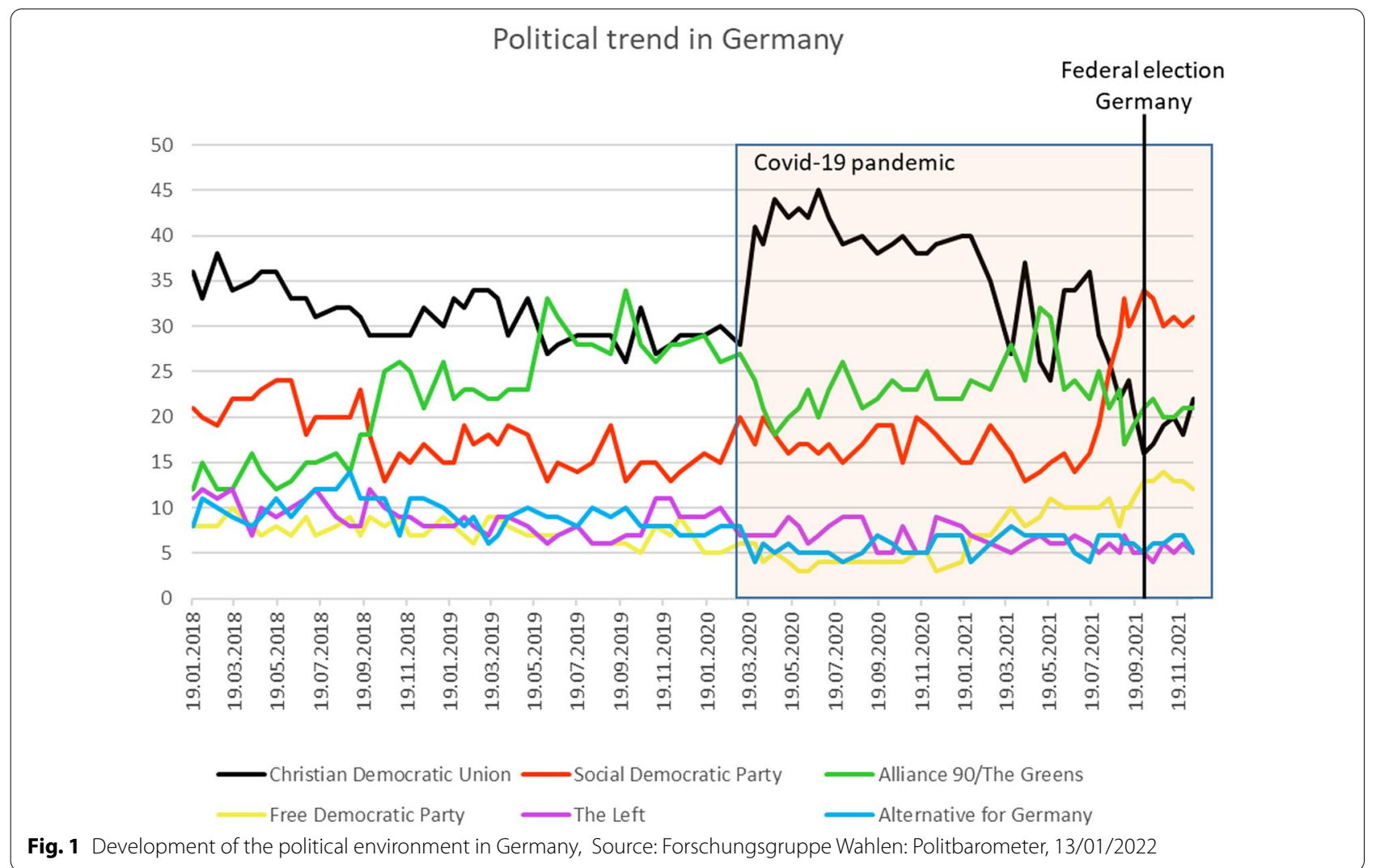

20,000 new contracts from January until June 2018, which-according to a spokesperson for Lichtblick-is far more than in recent years. He believes the climate debate plays an important role in this [65].

The effect of climate change awareness on voter behavior Whereas past research has shown that behavioral changes, especially in the context of sustainability, often come along with an attitude-behavior gap [66], this gap (i.e., the barriers to behavioral change) are much lower in voting decisions, so that voter behavior can be a much more direct reflection of the effects of increased climate change awareness and the respective changes in public opinion.

\section{Voter behavior and political participation}

An often used indicator for the public's attitudes towards environmental issues in Germany has been the popularity of the Bündnis 90/Die Grünen (Alliance 90/ The Greens), a political party specifically addressing objectives of 'green politics' and the objective to promote climate protection and an ecologically sustainable society [67]. In this regard, recent data from Politbarometer, an organization that regularly surveys political trends in Germany, provides interesting observations (Fig. 1): since the early 1990s, the Alternative 90/The Greens have fluctuated between approximately 5 and $15 \%$ of the votes. However, in September/October of 2018 the stated preference for this party increased sharply to more than $22 \%$ in November 2018 [68]. Another, second sharp increase was reported for the period from May to June of 2019: at this time, just before the European Elections, a YouTuber called Rezo published a video, in which he extensively blames the traditional German political parties (especially the Christian Democratic Union and the Social Democratic Party) for contributing to ever diverging 
social disparities and for accelerating climate change [69, 70]. This video has been viewed more than 17 mio. times and was the most viewed YouTube video in Germany in 2019 [70, 71], and in the aftermath more than $25 \%$ of the people stated their preference for the Green Party [68]. The publication of this video certainly served as a further energizer promoting climate change awareness among the German population.

Although, with a share of $20.5 \%$ of votes for the Greens in the election of the European Parliament in Germany in May 2019, these survey predictions of over $25 \%$ were not fully confirmed, this result marked an increase in votes by nearly $10 \%$ as compared to the previous election in 2014 and was by far the party's best result ever in European elections. According to Bukow [69], this gain in votes can only be explained by the developments regarding environmental and climate protection policies-no other topic was more decisive for the election, and no other party was perceived to be as competent in this field as the Alliance 90/The Greens. Demographically, in all age groups under 60 the Alliance 90/The Greens received the majority of the votes. It was merely the age group 60 years and up, in which a majority voted for the Christian Democratic Union (CDU) which lead to the overall win of this party [69]. Similarly, also in the 2021 German federal election the final result of $14.8 \%$ for the Greens did not confirm the predictions of well over $20 \%$ for the years between 2018 and 2020. However, nonetheless this result represents an increase by roughly $60 \%$ compared to the 2017 federal election (the Greens: 8.9\% in 2017). Figure 1 further shows the impact of the Covid-19 pandemic on the support of the different political German parties. Whereas the pandemic initially evoked strong public support for the leading governing party (CDU) and its approach to handling the pandemic (with a peak of 44\% in April of 2020), this tide turned as time went on, until finally roughly a month before the federal election the social democratic party (SPD) became the strongest party.

Furthermore, not only the election outcome, but also public participation in elections may be an important indicator. Voter turnout in the 2019 European Elections was the highest since 1994 (50.6\%). This increase was especially driven by the younger generation-in the age group of under 25-year-olds voter turnout increased by about $14 \%$, in the group of 25 - to 29 -year-olds it increased by $12 \%$ between 2014 and 2019. It can thus be surmised that the overall political interest increased [72].
During the same year 2019, three further state parliamentary elections were held in Germany. Whereas in the state of Bremen the Alliance 90/The Greens has been traditionally strong and their share of votes increased by 2.3\% (from 15.1\% to 17.4\%) between 2015 and 2019 [73], in Sachsen and Brandenburg it increased by $2.9 \%$ (from $5.7 \%$ to $8.6 \%$ ) [74] and by $4.6 \%$ (from $6.2 \%$ to $10.8 \%$ ) [75], respectively, during this time. The detailed analysis shows that the Alliance 90/The Greens gained votes in each one of the 16 German federal states. Across the states, the share of votes increased on average by $8.6 \%$ [76].

\section{Discussion}

In order to scrutinize the question of effectiveness, in this paper we conducted a review of available data to analyze whether climate change awareness does in fact manifest itself in behavioral changes towards climate protection, or whether it halts in the minds of people merely leading to controversial debates and either no or ambivalent behavioral responses in Germany.

Based on previous research, we considered two routes through which an increase in climate change awareness can instigate change: (a) directly by leading to behavioral changes towards more sustainable consumption and lifestyle decisions, or (b) indirectly by exerting pressure on the political process. As extension to this research, we paid specific attention to the household level in Germany [in the case of (a)], and the effects of voter behavior on political agenda-setting [in the case of (b)]. Furthermore, specific circumstances were considered, which during the relevant period (i.e., mainly the years 2018 and 2019) had influence on the surrounding social setting. These include the fact that an unusual heat and drought wave covered Europe during the summer of 2018.

The analyzed data in the three consumption sectors of mobility, food consumption and housing confirm the strong prevalence and impact of the attitude-behavior gap especially in the context of sustainability: although there is a broad, strongly positive attitude towards climate protection and increasingly high problem awareness of climate change, so far this attitude does not immediately translate into notable behavioral changes. Significant shifts were found for purchased electricity, where there is an unusual increase in green electricity contracts, and for the purchase of $\mathrm{CO}_{2}$ compensation 
for air travel. Both of these have been considered examples of indulgence trading or reassurance of guilty conscience, as both do not require true or lasting changes in behavior. Further, remarkable shifts were also observed for meat consumption and the purchase of organic food for 2019 compared to previous years. This, however, may have been influenced by further factors besides a climate change awareness effect. Whether there will be further shifts towards actual and more sustainable lifestyle decisions will have to be carefully monitored in the coming years, as relevant data are only now becoming available. With regard to effects on political agenda-setting, however, the effects are much more immediate. Again, future research will have to carefully monitor to what extent this pressure will actually translate into more profound climate protection measures and policies.

\section{Conclusion}

As the analysis shows, increased climate change awareness has spurred significant dynamics in the debate around climate change and sustainability both among the population and in the political realm. Fueled by the intense media coverage of the Fridays For Future movement and related activities, a snowball effect has been set off, opening a window of opportunity for significant shifts towards more effective and rigorous climate policies [77]. Politicians and decision-makers now have the opportunity to implement sustainability measures with strong support of the population, even if these imply higher costs. Furthermore, this 'climate change awareness window of opportunity' happens to coincide with a second window of opportunity for changes in climate policy, namely one opened by the economic support programs following the Covid-19 Pandemic. Currently, immense publicly funded rescue packages are being debated and developed for the relief of economic losses caused by the Covid-19 crisis. This public funding could be linked to sustainability obligations (e.g., climate mitigation measures, reduced resource intensity, circular use of materials, the replacement of fossil resources by renewable ones, etc.) including also standards of social sustainability. There are now first indications, however, that this latter opportunity will be forgone.

Nonetheless, the urgency of the Covid-19 pandemic showed in an effective manner that, when needed, the German administration is able to change policies and even significantly reduce economic activities to a certain degree even on very short notice. Climate activists have underlined the very similar urgency for effective climate and environmental policies. Therefore, the formerly often mentioned economic arguments against immediate policy changes can now be questioned providing a possibility for activist actions and new lines of argumentations. The decided German coal phase-out by 2038 and the corresponding structural change process, especially in the three main lignite mining regions in Germany (i.e., the Rheinische Revier, the Lausitzer Revier and the Mitteldeutsches Revier) currently serve as a key cornerstone for the transformation towards a new sustainable economy, which will be funded by over 40 billion Euros in the coming years. In light of these new dynamics, research should closely accompany the upcoming developments providing constant monitoring and feedback regarding their sustainability. More research will also be needed to determine whether there is actually a lasting shift in paradigm regarding the climate crisis and the environment caused by increased climate change awareness, both in terms of the analyzed lifestyle and consumption decisions as well as with respect to policy-making.

\section{Appendix}

See Table 3.

Table 3 Absolute changes in identified indicators

\begin{tabular}{|c|c|c|c|c|c|}
\hline Sector & Indicator & 2016 & 2017 & 2018 & 2019 \\
\hline \multirow[t]{3}{*}{ Mobility } & $\%$ of SUVs of the registration of new cars & 12.7 & 15.2 & 18.3 & 21.2 \\
\hline & number of air passengers in 1000 & 218.419 & 225.755 & 237.300 & 247.192 \\
\hline & Railway mileage in mill. km & 94.196 & 95.530 & 98.069 & 100.009 \\
\hline \multirow[t]{3}{*}{ Food consumption } & Meat in kg/capita/year & 60.5 & 60.0 & 60.2 & 59.5 \\
\hline & Expenses for organic food in billion $€$ & 9.84 & 10.34 & 10.91 & 11.97 \\
\hline & Vegetarians in million people & 5.29 & 5.70 & 6.31 & 6.10 \\
\hline Housing & Million people consuming green electricity & 9.74 & 10.51 & 11.42 & 12.67 \\
\hline
\end{tabular}




\section{Acknowledgements}

We would like to thank Dagmar Fiedler for her valuable advice and support throughout the publication process.

\section{Authors' contributions}

SV: contributed the research idea and conception; contributed to the data analysis; contributed to the writing of the manuscript; revised the manuscript. $\mathrm{MH}$ : contributed to the conception; contributed to the data analysis; contributed to the writing of the manuscript. MB: contributed to the data analysis; contributed to drafting the manuscript. All authors read and approved the final manuscript.

\section{Funding}

Open Access funding enabled and organized by Projekt DEAL. The research was funded by the Deutsche Forschungsgemeinschaft (DFG, German Research Foundation) - 491111487 and the Helmholtz Association of German Research Centers.

\section{Availability of data and materials}

All data generated or analyzed during this study are included in this published article.

\section{Declarations}

\section{Ethics approval and consent to participate}

Not applicable.

\section{Consent for publication}

Not applicable.

\section{Competing interests}

The authors declare that they have no competing interests.

\section{Author details}

'IEK-STE, Forschungszentrum Jülich, Wilhelm-Johnen-Straße, 52428 Jülich, Germany. ${ }^{2}$ School of Business and Economics, RWTH Aachen, 52072 Aachen, Germany.

Received: 24 June 2021 Accepted: 26 January 2022

Published online: 09 February 2022

\section{References}

1. Wolff R. 15-jährige Aktivistin aus Schweden: Greta schwänzt die Schulefürs Klima. tazde. https://taz.de/15-jaehrige-Aktivistin-aus-Schweden/ $! 5528023 / 2018$

2. Hecking C (2018) Gretas Aufstand. Spiegel Online

3. Schreuer M, Peltier E, Schuetze CF. Teenagers Emerge as a Force in Climate Protests Across Europe. The New York Times. https://www.nytimes. com/2019/01/31/world/europe/climate-change-protests-students.html2 019

4. Ehlerding S. Grawurzelbewegung für mehr Klimaschutz. tagesspiegelde. https://www.tagesspiegel.de/gesellschaft/panorama/klimawandel-grasw urzelbewegung-fuer-mehr-klimaschutz/23835062.htm|2019

5. Fridays For Future. Statistics / List-countries. https://www.fridaysforfuture. org/statistics/list-countries 2020

6. Shell. Shell Jugenstudie. Hamburg2019.

7. Rucht D, Sommer M (2019) Fridays for Future. Vom Phänomen Greta Thunberg, medialer Verkürzung und geschickter Mobilisierung: Zwischenbilanz eines Höhenflugs. Int Pol 4:121-125

8. Yuana SL, Sengers F, Boon W, Hajer MA, Raven R (2020) A dramaturgy of critical moments in transition: understanding the dynamics of conflict in socio-political change. Env Innov Soc Transit 37:156-170

9. Kollmann T (1998) Akzeptanz innovativer Nutzungsgüter und -systeme. Springer Verlag, Wiesbaden

10. Simon B (2011) Wissensmedien im Bildungssektor-Eine Kazeptanzuntersuchung an Hochschulen. Wien
11. Bauske E, Kaiser F (2019) Umwelteinstellung in Deutschland von 1996 bis 2016: Eine Sekundäranalyse der Umweltbewusstseinsstudien. In: Umweltbundesamt, editor. Texte

12. European Commission (2014) Special Eurobarometer 409 Climate Change. In: Commission E, editor. Special Eurobarometer

13. European Commission (2017) Special Eurobarometer 459 Climate Change. In: Commission E, editor. Special Eurobarometer

14. Europeean Commission (2019) Special Eurobarometer 490 Climate Change. In: Commission E, editor. Eurobarometer

15. Ipsos (2018) Climate Change Report 2018. In: Ipsos, editor

16. Dickman A, Skinner G (2019) Climate change and the wheater. In: Ipsos, editor

17. Ipsos (2020) Climate change and consumer behavior. In: Ipsos, editor

18. Boyon N (2019) United Nations Sustainable Development Goals- Global attitudes towards its use and regulation. In: Ipsos, editor. Survey for the World Economic Forum

19. Jackson C, Boyon N (2019) How does the world perceive our changing environment. In: Ipsos, editor. News and Polls: News

20. Setton D, Tomala J, Matuschke I, Toth-Feher N, Wolf I (2019) Social Sustainability Barometer for the German Energiewende. Potsdam: Institute for Advanced Sustainability Studies

21. Farjam M, Nikolaychuk O, Bravo G (2019) Experimental evidence of an attitude-behaviour gap in high-cost situations. Ecol Econ 166

22. Yamoah FA, Acquaye A (2019) Unravelling the attitude-behaviour gap paradox for sustainable food consumption: insight from the UK apple market. J Clean Prod 217:172-184

23. Park HJ, Lin LM (2020) Exploring attitude-behavior gap in sustainable consumption: comparison of recycled and upcycled fashion products. J Bus Res 117:623-628

24. Kollmuss A, Agyeman J (2002) Mind the Gap: why do people act environmentally and what are the barriers to pro-environmental behavior? Environ Educ Res 8

25. Diekmann A, Preisendörfer P (1998) Environmental behavior: discrepancies between aspirations and reality. Ration Soc 10:79-102

26. Destatis (German Federal Statistical Office) (2019) Environmental Economic Accounting - Direct and indirect CO2 emissions in Germany 2010-2015

27. Dubois G, Sovacool B, Aall C, Nilsson M, Barbier C, Herrmann A, et al (2019) It starts at home? Climate policies targeting household consumption and behavioral decisions are key to low-carbon futures. Energy Res Soc Sci

28. Moberg KR, Aall C, Dorner F, Reimerson E, Ceron J-P, Sköld B, et al. (2018) Mobility, food and housing: responsibility, consumption and demandside policies in deep European Decarbonisation pathways. Energ Effic 12

29. German Federal Motor Transport Authority (KBA) (2020) Neuzulassungen im Jahr 2020 nach Segmenten

30. German Federal Ministry of Transport and Digital Infrastructure (BMVI) (2020) Verkehr in Zahlen 2019

31. Statista (2020) Pro-Kopf-Konsum von Fleisch in Deutschland in den Jahren 1991 bis 2019 (in Kilogramm)

32. German Organic Food Production Alliance (BÖLW) (2020) Umsätze und Umsatzanteile für Öko-Lebensmittel in Deutschland nach Absatzebenen

33. Statista (2020) Anzahl der Personen in Deutschland, die sich selbst als Vegetarier einordnen oder als Leute, die weitgehend auf Fleisch verzichten*, von 2014 bis 2019 (in Millionen)

34. Statista (2020) Bevölkerung in Deutschland nach Bezug von Ökostrom von 2016 bis 2019 (Personen in Millionen)

35. Rodrigue J-P, Slack B, Comtois C (2017) The geography of transport systems, 4th edn. Routledge, London

36. Grewe V (2018) Climate Impact of Aviation $\mathrm{CO} 2$ and non-CO2 effects and examples for mitigation options. In: DLR, editor. Aviation long-term decarbonisation workshop

37. Umweltbundesamt (2019) Fahrleistungen, Verkehrsaufwand und "Modal Split". In: Umweltbundesamt, editor. Data about Traffic

38. Radke S (2018) Verkehr in Zahlen 2018/2019. 47. Jahrgang ed. Flensburg: Kraftfahrt-Bundesamt

39. Smidfelt Rosqvist $L$ (2019) Understanding high car use in relation to policy measures based on Swedish data.

40. Lukman R, Lozano R, Vamberger T, Krajnc M (2013) Addressing the attitudinal gap towards improving the environment: a case study from a primary school in Slovenia. J Clean Prod 48:93-100 
41. Lane B, Potter S (2007) The adoption of cleaner vehicles in the UK: exploring the consumer attitude-action gap. J Clean Prod 15:1085-1092

42. Kraftfahrtbundesamt (2019) Neuzulassungen von Personenkraftwagen nach Segmenten und Modellreihen. In: Kraftfahrtbundesamt, editor. Dresden, Germany

43. Kraftfahrtbundesamt (2019) Jahresfahrleistung alle Fahrzeuge. Dresden, Germany

44. Umweltbundesamt (2020) Fahrleistungen, Verkehrsaufwand und "Modal Split". In: Umweltbundesamt, editor. Verkehr

45. Kraftfahrtbundesamt (2020) Kurzbericht Verkehr in Kilometern

46. Statistisches Bundesamt (2019) Statistische Wochenberichte-Wirtschaft, Handel und Verkehr. In: Bundesamt S, editor. Wirtschaft, Handel und Verkehr-Monatszahlen

47. Strittmaier K (2019) Und sie schämen sich doch. Süddeutsche Zeitung

48. Bundesverband der Deutschen Luftverkehrswirtschaft (2020) Jahresbilanz 2019-Zur Lage der deutschen Luftverkehrswirtschaft. Bundesverband der Deutschen Luftverkehrswirtschaft BDL

49. Ly TD (2020) Travelers don't walk the green talk—here's what to do. travelandmobilitytech

50. Statistisches Bundesamt (2019) Mehr Fluggäste weniger Luftfracht im ersten Halbjahr 2019. In: Statistisches Bundesamt, editor. Pressemitteilung Nr 320 vom 26 August 2019. Wiesbaden, Germany

51. Statistisches Bundesamt (2020) Pressemitteilung Nr.050 vom 18. Februar 2020. In: Statistisches Bundesamt, editor. Wiesbaden, Germany

52. Berton E (2019) Flight shaming hits air travel as 'Greta effect' takes off. Reuters

53. Abington T (2019) Greta Thunberg and 'Flight Shame' Are Fueling a Carbon Offset Boom. Bloombergcom:N.PAG.

54. Kiani-Kreß R (2019) "Wir sind Teil der Lösung". WirtschaftsWoche NR 041 vom 04102019 Seite 054

55. Naidu-Ghelani R (2019) Flight-shaming: Would you change your travel plans to save the planet? World Economic Forum: Ipsos

56. Ipsos MORI (2019) Concern about climate change reaches record levels with half now'very concerned'. United Kingdom

57. Atmosfair (2020) Jahresberichte und Dokumentation. Atmosfair

58. Bundesanstalt für Landwirtschaft und Ernährung BLE (2019) Bericht zur Markt- und Versorgungslage Fleisch 2019. In: BLE BfLuE, editor. Bonn, Germany

59. Agrarmarkt-Information AMI (2020) Verbraucher kaufen weniger Fleisch und Fleischwaren. In: AMl, editor

60. Kohlmüller M (2020) Meat consumption in Germany

61. Hamm U (2020) Impact factors of the demand for organic products

62. Bundesverband Naturkost Naturwaren BNN (2020) Greta-Effekt: Biobranche in Deutschland boomt. In: Vegconomist, editor

63. Haffert C (2019) "Greta-Effekt" am Strommarkt. Nordwest Zeitung

64. El-Sharif Y (2019) Der "Greta-Effekt" auf dem Strommarkt. Spiegel Online: Spiegel

65. Risch C (2019) Norddeutschland Neuverträge "Greta-Effekt": Immer mehr Stromkunden wechseln in Öko-Tarife. In: Lübecker Nachrichten, editor.: Lübecker Nachrichten

66. Hirsch D, Terlau W (2015) Sustainable consumption and the attitudebehaviour-gap phenomenon-causes and measurements towards a sustainable development. Int J Food Sys Dyn 6:159-174

67. Bündnis 90/Die Grünen (2020) Bündnis 90/Die Grünen

68. Forschungsgruppe Wahlen (2020) Projektion seit 1991: wenn am nächsten Sonntag wirklich Bundestagswahl wäre... In: Zweites Deutsches Fernsehen ZDF, editor. Politbarometer. Mainz, Germany

69. Bukow S (2019) Europawahl in Deutschland 2019: Ergebnisse und Analysen. In: Stiftung B, editor. böllbrief Demokratie \& Gesellschaft: Böll Stiftung

70. Rezo ja lol ey (2019) Die Zerstörung der CDU

71. SpotOnNews. Das sind die Top-Videos des Jahres 2019. In: Stern, editor. Unangefochten führt Rezodie Liste der meistgesehenen YouTube-Videos 2019 an In Sachen Musik dominiert der Deutschrap: Stern; 2019

72. Eurobarometer (2019) Eurobarometer Spezial EP 91.5

73. Land Bremen. Bürgerschaftswahl Gesamtergebniss. http://www.wahlenbremen.de/Wahlen/2019_05_26/04010000/html5/index.html2019

74. Landtag Sachsen. Sitzverteilung im 7. Sächischen Landtag. https://www. landtag.sachsen.de/de/landtag/wahlen-gesetzgebung/wahlergebnisseund-sitzverteilung.cshtml2019
75. Landeswahlleiter für Brandenburg. Brandenburger Wahlergebnisse. https://www.wahlergebnisse.brandenburg.de/wahlen/LT2019/diagr amSitze.html2019

76. Federal Election Commissioner. Sitzverteilung. https://www.bundeswahl leiter.de/europawahlen/2019/ergebnisse/bund-99.html2019

77. Hake J-F, Fischer W, Venghaus S, Weckenbrock C (2015) The German Energiewende-history and status quo. Energy 92:532-546

\section{Publisher's Note}

Springer Nature remains neutral with regard to jurisdictional claims in published maps and institutional affiliations.
Ready to submit your research? Choose BMC and benefit from:

- fast, convenient online submission

- thorough peer review by experienced researchers in your field

- rapid publication on acceptance

- support for research data, including large and complex data types

- gold Open Access which fosters wider collaboration and increased citations

- maximum visibility for your research: over $100 \mathrm{M}$ website views per year

At BMC, research is always in progress.

Learn more biomedcentral.com/submissions 